\title{
Gender responsiveness in forest management towards sustainable development
}

\author{
Ryza Dani Pratiwi ${ }^{1, *}$, Ismi $_{\text {Dwi Astuti Nurhaeni }}{ }^{1}$, and Drajat Tri Kartono ${ }^{1}$ \\ ${ }^{1}$ Magister of Public Administration, Faculty of Social and Political Sciences of Universitas Sebelas \\ Maret, Surakarta, Indonesia
}

\begin{abstract}
Sustainable development as a development process giving environmental aspect needs attention. As an effort to reach sustainable development, the United Nations envisioned comprehensive vision to reach the better world in 2030 through Sustainable Development Goals (SDGs). Gender equality and land ecosystem are considered two of seventeen objectives of SDGs, where land ecosystem covers forest management to actualize sustainable forest. Since 2000 the Indonesian government echoed gender mainstreaming strategy through genderperspective integration in various fields of development. Even, the Forest Minister in 2011 and 2017 issued regulation on gender mainstreaming in living environment and forestry. This research aims at studying gender responsiveness of policy on forest management. It is a qualitative descriptive research conducted in Central Java Province since the location constitutes a preserved forest with wide critical land. Documentation studies and in-depth interview were employed as data collecting technique. The research result reveals that forest management in the national level is gender-responsive, namely it has considered the different needs between men and women. However, policy in the local level is still neutral gender. Women have access towards forest sources but they don't have control on it. The social norms about gender role contributed to gender relation in forest management.
\end{abstract}

\section{Introduction}

Sustainable development is a juxtaposition of two elements, they are "durable" and "development" [1]. The concept of sustainability is a fairly complex approach that arises from the environment that comes from various human activities. In principle, development will generate growth and the environment to reduce poverty and also build prosperity for the current population in addition to shared needs [2]. Issues related to development are currently the focus for countries in the world, this is evidenced by the agenda of 2030 for Sustainable Development (Agenda 2030 for Sustainable Development or SDGs). Efforts to achieve of Sustainable Development Goals (SDGs), the President of the Republic of Indonesia has presidential regulation number 59 years 2017 concerning Implementation of Achieving Sustainable Development Goals. The regulation is a guideline for Ministries or

\footnotetext{
* Corresponding author: ryzadanipratiwi@student.uns.ac.id
} 
Institutions and Regional Governments in the preparation, implementation, monitoring and evaluation of the SDG Budget Plan). At the provincial level, Central Java is one of the provinces that have adopted the SDG through Governor Decree Number 050/13 of 2018 concerning the Establishment of the Regional Coordination Team and the Working Group for the Implementation of Central Java Sustainable Development Goals Year 2018-2023 and Decree of the Secretariat Number 050.2 / 6147 of 2018 concerning the Establishment of the Team of the Secretariat of the Sustainable Development Goal of Central Java Province.

Indonesia has a vast forest area of $120,773,441.71$ ha, so Indonesia has an important role in reducing the impact of global climate change. The efforts of the Indonesian government in forest management, contained in various regulations include (a) Law No. 41 of 1999 concerning Forestry, (b) Law No. 24 of 2007 concerning Disaster Management, (c) Law No. 32 of 2009 concerning Environmental Protection and Management, and many more. The definition of critical land differs from one institution to another because of differences from each user. From an agricultural point of view, critical land with production while from a forestry perspective views critical land as being associated with functions as a water-regulating medium, a medium for producing forest products and as a flood protection medium or downstream sedimentation (Didu, 2001). The number of critical lands in Indonesia in 2013 stood at 24,196,000 ha with a critical status of 19,565,000 ha and a very critical status of 4,632,000 ha.

In forest management, community participation (both men and women) around the forest is very influential. Sinery and Manusawai [3] stated that in the perspective of conservation of natural resources, community participation in program management is a fundamental thing that determines the success of program implementation. Programs that involve communities in forest management provide significant results in supporting the achievement of SDGs [4]. Although community participation is very influential in forest management, inequality between men and women is still found, especially their access to forests, and how they use forest resources [5]. In addition, the role of men is more dominant in productive activities and decision making, while women are more dominant in reproductive activities [6 - 8]. Nurhaeni's research [9] regarding women's participation in environmentally friendly tourism management in the Gunung Lawu area shows that women in the Gunung Lawu area have lower competencies, higher internal barriers and limited women's empowerment policies in environmentally friendly tourism development. Therefore, a gender responsive forest management policy is an urgent demand that both forest men and women can manage and utilize forest products fairly and equally.

Basically efforts to ensure justice and gender equality have received support both at the global and national levels. At the global level, at the UN General Assembly meeting, the Convention on the Elimination of All Discrimination Against Women (CEDAW) was approved. Then at a conference organized by the United Nations in Beijing-China, at the conference the strategic goals that must be achieved from the 12 critical areas agreed upon. Research related to forest management is still focused on the study of communication of participation in forest management [10], policy reform, environment and agriculture [11], evaluation of forest management policy models [12], women's perspectives in ecosystem services [13], gender challenges in the forestry industry [14], chaos theory on forestry policy [15], political deliberative in forestry policy reform [16], forest management sustainable [17] and access and control between men and women in managing community forest resources [18]

Therefore, this research focuses on the study of gender responsiveness of government policies in the forestry sector. Gender analysis related to policy will refer to Kabeer's theory (in March, 1999) which classifies policies into two categories, namely gender blind policy and gender conscious policy, and classifies gender-aware policies into 3 (three) sub 
categories, namely gender-neutral policies, policies gender specific and gender redistributive policies. The results of this study will provide benefits in designing public policies at the regional government level that are more gender responsive, especially in supporting forest sustainability and sustainable development.

\section{Methods}

The study uses a qualitative approach with the aim of understanding the phenomenon of what is experienced by research subjects holistically, and by way of descriptions in the form of words and languages, in a specific natural context and by utilizing various scientific methods (Moleong, 2007). Location of this research was carried out in the Community Forest area managed by the Province of Central Java, especially in the Regional Forest Management Agency IX of the Environment and Forestry Office of Central Java Province. The data used in this study are secondary data in the form of policy documents which according to Permendagri 67 of 2011 must integrate a gender perspective. The design of this research is evaluation research. Evaluation research is a method for obtaining feedback for a program, so that implementers can increase their effectiveness [19, 20].

The researcher used the data collection technique in the form of (1) documentation at the Central Java Provincial Environment and Forestry Service. The data collected in the form of data about the Strategic Plan of the Ministry of Environment and Forestry of the Republic of Indonesia in 2014 - 2018; Central Java Provincial Medium-Term Development Plan 2014-2018; Strategic Plan of the Central Java Provincial Environment and Forestry Office for 2014 - 2018 and the Work Plan for the Central Java Provincial Environment and Forestry Service in 2018; (2) Interview with informants namely Officials in forest management, Staff of Extension and Forest Protection Section, Staff of Forest and Land Rehabilitation Section in Central IX Forest Management Center. (3) Observation on the implementation of activities in the area of BPH IX, namely the distribution of seeds to forest farmer groups

The analysed aspect is gender responsiveness in local government policies in supporting forest management policies in Central Java Province by classifying policies into three categories according to Kabeer (March, 1999): Gender Neutral, the policy is said to be gender neutral if the policy does not favor one sex; Gender Specific, policies are said to be gender specific if they are based on knowledge of gender differences in a particular context to respond to the practical needs of gender specifically for women or men; and Redistributive Gender, policies that are intended to renew the distribution of power and resources available to create a more equal relationship between men and women by touching on the strategic needs of gender. The data analysis technique used in this study is the analysis of the contents of policy documents. Technically content analysis includes efforts: 1) classification of signs used in communication; 2) using criteria as a basis for classification; 3) using certain analytical techniques to make predictions [20].

\section{Results and discussion}

To achieve sustainable development goals, a gender responsive policy is needed so that the results of each program have a significant impact on both men and women. Policies at the central and provincial levels are contained in regional development planning documents. In this study, the Office of Environment and Forestry of Central Java Province is the Office of implementing elements of governmental affairs in the field of Environment and Forestry which are the authority of the Region stipulated by Regional Regulation 
Number 9 of 2016 concerning the Establishment and Composition of Regional Devices of Central Java Province.

To find out the gender responsiveness of forest management policies in Central Java Province, an analysis of several policy documents will be carried out, including the Regional Medium-Term Development Plan (RPJMD) of Central Java Province 2013 2018; Strategic Plan of the Environment and Forestry Office (DLHK Strategic Plan) of Central Java Province 2013-2018 and concludes with the Environmental and Forestry Service Work Plan (Renja DLHK) of Central Java Province in 2018.

\subsection{Gender responsiveness analysis of regional medium-term development plan (RPJMD) of Central Java Province 2013 - 2018}

To find out the gender responsiveness of forest management policies at the Central Java Provincial level, the analysis will be carried out in the Central Java Provincial Development Plan (RPJMD) document for 2013 - 2018 Province. 2017 concerning changes to the Central Java Provincial Regulation Number 5 of 2014 concerning the Regional Medium-Term Development Plan (RPJMD) of Central Java Province 2013 - 2018. The analysis will begin with the vision, aim, target, strategies, policy direction (Table 1)

Table 1. Gender responsivness analysis of regional medium-term development plan (RPJMD) of Central Java Province 2013 - 2018.

\begin{tabular}{|c|c|c|c|c|c|}
\hline \multirow{2}{*}{$\begin{array}{c}\text { Policy } \\
\text { Component }\end{array}$} & \multirow{2}{*}{$\begin{array}{l}\text { Amount } \\
\text { of } \\
\text { Formula } \\
\text { tion }\end{array}$} & \multirow{2}{*}{$\begin{array}{l}\text { Amount of } \\
\text { Translation }\end{array}$} & \multicolumn{2}{|c|}{ Analysis Results } & \multirow[b]{2}{*}{ Explanation } \\
\hline & & & $\begin{array}{l}\text { Gender } \\
\text { Neutral }\end{array}$ & $\begin{array}{c}\text { Gender } \\
\text { Responsive }\end{array}$ & \\
\hline Vision & 1 & 2 & 1 & 1 & $\begin{array}{l}\text { There are "sustainable" } \\
\text { statements in exploring } \\
\text { and utilizing natural } \\
\text { resources }\end{array}$ \\
\hline Mission & 7 & 7 & 5 & 2 & $\begin{array}{l}\text { There are "equality" } \\
\text { and "sustainability" } \\
\text { statements }\end{array}$ \\
\hline Aim & 28 & 28 & 27 & 1 & $\begin{array}{l}\text { There are "equality" } \\
\text { statements }\end{array}$ \\
\hline Target & 55 & 55 & 52 & 3 & $\begin{array}{l}\text { There are "gender } \\
\text { equality, "women } \\
\text { protection", "equity" } \\
\text { statement }\end{array}$ \\
\hline Strategies & 76 & 76 & 74 & 2 & $\begin{array}{l}\text { There are "gender } \\
\text { mainstreaming" and } \\
\text { "women } \\
\text { protection"statements }\end{array}$ \\
\hline $\begin{array}{l}\text { Policy } \\
\text { direction }\end{array}$ & 80 & 80 & 78 & 2 & $\begin{array}{l}\text { There are "gender } \\
\text { mainstreaming" and } \\
\text { "women } \\
\text { protection"statements }\end{array}$ \\
\hline
\end{tabular}


Based on the analysis in the Regional Medium-Term Development Plan (RPJMD) of Central Java Province 2013 - 2018 it can be concluded that although most policies are included in the gender neutral category, gender issues have been integrated in policy documents explicitly and consistently both in the vision, mission, goals, objectives, strategies and policy directions.

\subsection{Gender responsiveness analysis of strategic plan for the department of environment and forestry of Central Java Province 2013 - 2018}

Document analysis was carried out in the Strategic Plan for the Department of Environment and Forestry of Central Java Province 2013 - 2018. The Environmental and Forestry Agency Strategic Plan for 2013 - 2018 was prepared with the intention of providing a medium-term planning document for the Central Java Provincial Environment and Forestry Service that can ensure the direction of performance towards achieving the strategic development goals of Environment and Forestry in Central Java.

In the Strategic Plan of the Department of Environment and Forests Year 2013 - 2018 stated that the vision of the Department of Environment and Forests of Central Java province supports the vision of Central Java province. While the mission of the Central Java Provincial Environment and Forestry Service supports the 7th Mission in the Central Java RPJMD 2013-2018. The 7th mission aims to implement environmentally friendly concepts in every development. Based on the results of the previous analysis, the 7th Mission entered into the gender responsive category, therefore it was concluded that the mission of the Central Java Provincial Environment and Forestry Service was gender responsive.

The analysis then continued to the objectives of the Environment and Forestry Service of Central Java Provincial. There are 4 objectives to be achieved during the period 2013 2018. The results of the analysis identify that all objectives are stated in sentences that fall into the gender neutral category. Then from these goals are elaborated into 11 targets, out of the 11 targets included in the gender neutral category. The analysis then continues on general strategies and policies. There are 11 strategies and 11 general policies. However, the results of the analysis show that the strategy and direction of the Central Java Provincial Office of Environment policy are expressed in gender neutral.

There are 15 programs listed in the Strategic Plan for the Department of Environment and Forestry of Central Java Province 2013 - 2018, out of 15 programs it was identified that all programs were explicitly included in the gender neutral category. After analyzing the programs, then the analysis is carried out on activities carried out to support the achievement of goals and objectives. There were 52 activities outlined in the Strategic Plan for the Department of Environment and Forestry of the Province of Central Java in 2013 2018. Of the total activities there were 1 activity included in the gender responsive category.

Based on the results of the analysis in the Strategic Plan for the Department of Environment and Forestry of Central Java Province 2013 - 2018 it is known that starting from the vision, mission, activities and activity indicators of the Department of Environment and Forestry of Central Java Province, gender responsiveness has been taken. Although there are policies that explicitly include gender issues for these activities it is not an activity that supports forest management. These activities are more directed towards environmental management. 
Table 2. Gender responsivness analysis of strategic plan for the Department of Environment and Forestry of Central Java Province $2013-2018$.

\begin{tabular}{|c|c|c|c|c|}
\hline \multirow{2}{*}{$\begin{array}{l}\text { Policy } \\
\text { Component }\end{array}$} & \multirow{2}{*}{$\begin{array}{c}\text { Amount of } \\
\text { Formulation }\end{array}$} & \multicolumn{2}{|c|}{ Amount of Translation } & \multirow[b]{2}{*}{ Analysis Results } \\
\hline & & Gender Neutral & $\begin{array}{l}\text { Gender } \\
\text { Responsive }\end{array}$ & \\
\hline Vision & 1 & 0 & 1 & $\begin{array}{l}\text { There are } \\
\text { "sustainable" } \\
\text { statements in } \\
\text { exploring and utilizing } \\
\text { natural resources }\end{array}$ \\
\hline Mission & 1 & 0 & 1 & $\begin{array}{l}\text { There are } \\
\text { "sustainable" } \\
\text { statements }\end{array}$ \\
\hline Aim & 4 & 4 & 0 & \multirow{5}{*}{$\begin{array}{l}\text { There is no indication } \\
\text { of gender } \\
\text { responsiveness }\end{array}$} \\
\hline Target & 11 & 11 & 0 & \\
\hline Strategies & 11 & 11 & 0 & \\
\hline $\begin{array}{l}\text { Policy } \\
\text { direction }\end{array}$ & 11 & 11 & 0 & \\
\hline Programs & 15 & 15 & 0 & \\
\hline Activities & 52 & 51 & 1 & $\begin{array}{l}\text { There are "facilitation } \\
\text { of women" statements }\end{array}$ \\
\hline $\begin{array}{l}\text { Activity } \\
\text { Indicators }\end{array}$ & 36 & 35 & 2 & $\begin{array}{l}\text { The learning of } \\
\text { environmental cadres } \\
\text { where the cadres are } \\
\text { women. }\end{array}$ \\
\hline
\end{tabular}

\subsection{Gender responsiveness analysis of strategic plan for the department of environment and forestry of Central Java Province 2013 - 2018}

To find out the extent of gender integration in policy documents, an analysis will be carried out in the Department of Environment and Forestry Work Plann 2018. The work plan is a document that belongs to each regional organization that contains plans for activities to be carried out within one year. In 2018, the Department of Environment and Forestry carried out a series of programs and activities to achieve the vision and mission of Central Java Province.

The results of the identification in the 2018 Central Java Provincial Office of Environment and Forestry Work Plan found that the elaboration of the program in the 2018 Central Java Provincial Environment and Forestry Work Plan explicitly falls into the gender neutral category. Whereas in its activities there is one gender responsive activity with gender responsive indicators because one of the activities is aimed at increasing knowledge and skills for women. 


\section{Conclusion}

The conclusions are, in the Regional Medium-Term Development Plan (RPJMD) of Central Java Province 2013 - 2018 it can be concluded that although most policies are included in the category of gender neutrality, gender responsiveness has been explicitly integrated in policy documents both consistently on the vision, mission, goals, goals, strategies and policy directions. While the results of the analysis in the Strategic Plan for the Department of Environment and Forestry of Central Java Province 2013 - 2018 are known that starting from the vision, mission, activities and indicators of activities at the Department of Environment and Forestry, gender responsiveness has been achieved. The results of the identification in the Work Plan of Department of Environment and Forestry of Central Java Province found that the elaboration of the program in the Department of Environment and Forestry 2018 was explicitly included in the gender neutral category, while in its activities there was one gender responsive activity.

\section{References}

1. D.C. Duran, L.M. Gogan, A. Artene, V. Duran, Procedia Economics and Finance 26 806-811 (2015)

2. I.V Muralikrishna, V. Manickam, Environmental Management: Science and Engineering for Industry (Butterworth-Heinemann, UK, 2017)

3. A. S. Sinery, J. Manusawai, Jurnal Manusia dan Lingkungan 23, 3, 394-401 (2016)

4. W. De Jong, B. Pokorny, P. Katila, G. Galloway, P. Pacheco, Forest 9,1-18 (2018)

5. C. Manfre, D. Rubin, Integrating gender into forestry research: A guide for CIFOR scientists and programme administrators (CIFOR Indonesia, Bogor, 2012)

6. M. Suwardi, Analisis Gender Dalam Kegiatan Pengelolaan Hutan Rakyat Dan Kontribusi Hutan Rakyat Terhadap Pendapatan Rumah Tangga (Kasus Hutan Rakyat di Desa Sukaresmi, Kecamatan Sukaresmi, Kabupaten Cianjur, Jawa Barat) (Institut Pertanian Bogor, Bogor, 2010)

7. H. Hafizianor, R. Muhayah, S. Zakiah, Jurnal Hutan Tropis 3, 2, 133-144 (2015)

8. F. Rahmawati, M. Abdulkadir. Jurnal Sosiologi Pedesaan 01, 03, 206-221 (2013)

9. I.D.A, Nurhaeni, Reformasi Kebijakan Pemberdayaan Perempuan dalam Pengembangan Pariwisata Berwawasan Lingkungan Hidup di Kawasan Gunung Lawu (Kementerian Riset, Teknologi dan Pendidikan Tinggi RI, Jakarta, 2015)

10. N.S. Tanjung, D. Sadono, C.T. Wibowo, Jurnal Penyuluhan 1, 13, 14 - 30 (2017)

11. C. Brannstrom, Geoforum 36, 257-271 (2005)

12. T. Sukwika, D. Darusmas, C. Kusuma, D.R. Nurrochmat, Jurnal Pengelolaan Sumberdaya Alam dan Lingkungan 8, 2, 207-215 (2018)

13. Y.C.E. Yang, S. Passarelli, R.J Lovell, C. Ringler, Ecosystem Service 31, 58-67 (2018)

14. E. Andersson, G. Lidestav, Forest Policy and Economics 67, 38-44 (2016)

15. A. Vainio, R. Paloniemi, Land Use Policy 35, 247-256 (2013)

16. H.R. Ojha, M.R. Banjade, R.K. Sunam, B. Bhattarai, S. Jana, K.R. Goutam, S. Dhungana, Forest Policy and Economics 46, 1-9 (2014)

17. K.G, MacDicken, Forest Ecology and Management 352, 47-56 (2015)

18. F. Rahmawati, M.A Sunito, Sodality: Jurnal Sosiologi Pedesaan 1, 3, 206-221 (2013)

19. Wibawa, Samodra, Evaluasi Kebijakan Publik (PT Raja Grafindo Persada, Jakarta, 1994)

20. Sugiyono, Metode Penelitian Administrasi (Alfabeta, Bandung, 2010)

21. I.D.A Nurhaeni, Reformasi Kebijakan Publik Pendidikan Menuju Kesetaraan dan Keadilan Gender (Cakra Books, Solo, 2008) 